\title{
The Importance of Compensation and Benefits on University Students' Perceptions of Organizations as Potential Employers
}

\author{
Howard Adler ${ }^{1}$ \& Richard Ghiselli ${ }^{1}$ \\ ${ }^{1}$ School of Hospitality and Tourism, Purdue University, West Lafayette, USA \\ Correspondence: Howard Adler Ed.D, C.B. Smith Professor of Hotel Management, School of Hospitality and \\ Tourism, Purdue University, Marriott Hall, West Lafayette, Indiana 47906, USA. Tel: 765-494-5998. E-mail: \\ adlerh@purdue.edu
}

Received: November 4, 2014

Accepted: December 9, 2014

Online Published: January 5, 2015

doi:10.5430/jms.v6n1p1

URL: http://dx.doi.org/10.5430/jms.v6n1p1

\begin{abstract}
The present study examined university students' perceptions of compensation and benefits offered by companies they seek to work for upon graduation. An extensive review of the literature indicated a need for a better understanding of perceptions of university students regarding a companies overall employer brand which included compensation and benefits as factors that affect those perceptions. Students at a major university were surveyed and indicated the items related to compensation and benefits related to brand image which were most important to them were, good medical benefits, above average retirement plans and tuition reimbursement.
\end{abstract}

Keywords: human resource management, brand image, employer branding, recruitment, hospitality and tourism management students

\section{Introduction}

\subsection{Defining Employer Branding}

The "sum of a company's effort to communicate to existing and prospective staff that it is a good place to work" is how Lloyd (2002) described employer branding. It can also be seen as a set of distinctive images of a prospective employer in the minds of a particular group of employees or potential employees (Meffert, Burmann, \& Koers, 2002; Petkovic, 2004). It has also been referred to as a package of psychological, economic, and functional benefits provided by employment and identified with an employer (Thorne, 2004). Employer branding activities which the organization can help in attracting future employees (Yaqub \& Khan 2011). The purpose of employer branding is to display the benefits of the company in the minds of potential employees as a great place to work (an employer of choice) (Branham, 2001). Human resource advocates believe employer branding is crucial to recruit the best candidates (Willock, 2005).

An employer brand is the most important brand relationship an individual is likely to have in his/her life. It involves the brand of the organization which employs the individual. How people feel about their employer brand is increasingly critical to business success or failure (Mosley, 2009). Leading companies realize its importance in attracting and engaging the people they need to deliver profitable growth. An employer brand normally begins by analyzing a company's values, ideologies and organizational attributes. These are then converted to a so called value proposition which potential employees utilize in their decision whether to seek employment with that company or not (Chabra \& Sharma 2014).

\subsection{Organizational Attractiveness}

The notion of "employer attractiveness" is a closely related concept to "employer branding". Employer attractiveness has been defined as the envisioned benefits that a potential employee recognizes in working for a specific organization (Berthon, Ewing, \& Hah, 2005). The more attractive an employer is perceived by potential employees, the stronger that particular organization's employer brand equity (Berthon et al., 2005). Organizational attractiveness as an employer is defined as viewing an organization as a desired and positive place to work by potential employees (Ehrhart \& Ziegert, 2005; S. L. Rynes, 1991). Attraction of human resources is recognized as a source of competitive advantage (Turban \& Greening, 1997). Each year, Fortune magazine ranks companies that are the "100 Best Companies to Work For". Those companies are evaluated based on information about the firms' human resource practices such as pay and benefits, health programs, availability of work-life programs, diversity composition, and 
the number of hours of professional training for potential employees (Fortune, 2011). Companies spend resources vying for a position on the list, of ' 100 Best Companies to Work For'; they assume that being highly rated improves the company's brand image and supports attracting talented potential employees. Martin (2009) argued that the growth of interest in employer branding can be explained by "progressively more heated and global talent wars" ( $p$. 252), a point which can be supported by recent interest in organizations wanting to become an "employer of choice" and "best companies to work for". With increasingly competitive employment markets, developing strategies to become an employer of choice are vitally important. They can increase the number of applicants per vacancy and can facilitate the recruitment of sustainable employees as well as provide a strategic advantage to the firm (Wilden, Gudergan, \& Lings, 2010). Attracting competent job applicants is an important task for organizations (Backhaus, 2004). An overall brand name plays a major role in influencing a potential recruit to pursue a job (Kim, York, \& Lim, 2011).

The purpose of this study was to evaluate how university students viewed those factors related to compensation and benefits in relation to job decisions.

\section{Review of the Literature}

Successful employer branding generates a positive effect to impact potential employees' in the decision-making process (Backhaus, 2004; Lievens, Decaesteker, Coetsier, \& Geirnaert, 2001; Peter, 1999; S. L. Rynes \& Barber, 1990; Sullivan, 2004; Thomas \& Wise, 1999). Ambler and Barrow (1996) first applied the concept of brand to human resource management. They viewed the employer as the brand and the employee as the consumer and employer brand as "the package of functional, economic and psychological benefits provided by employment and identified with the employing company.

Lloyd (2002) defined employer brand as the image of the firm as "a desirable place to work" in the minds of existing and prospective staff. The term of "employer branding" is often used to describe how organizations market their offerings to existing and potential employees, communicating with them and maintaining their loyalty (Backhaus \& Tikoo, 2004). The employer brand can be viewed as "a set of attributes and qualities-often intangible that make an organization distinctive, promises a particular kind of employment experience, and appeals to those people who will thrive and perform best in its culture" (CIPD, 2009). Brand image informs potential employees of a company's attributes and reputation (Cable \& Turban, 2003; Lievens \& Highhouse, 2003). For companies in service industries, their business success may depend on building positive and strong employer brand images (Brannan, Parsons, \& Priola, 2011). Researchers have described distinctive branding as a vehicle for dealing with a competitive labor market. In addition, strong branding can be a tool for attracting potential employees and retaining current employees in the service industry (Brannan et al., 2011; De Chernatony \& Segal-Horn, 2003; Knox \& Freeman, 2006). The term suggests the differentiation of a firm's characteristics as an employer from those of its competitors. Employment brand highlights the unique aspects of the firm's employment offerings or environment (Backhaus \& Tikoo, 2004).

Employer branding describes the degree of a company's attractiveness to current (Berthon et al., 2005) and potential employees (Collins \& Stevens, 2002; Slaughter, Zickar, Highhouse, \& Mohr, 2004). It helps organizations focus on how they can identify themselves within their market as an employer of current staff, as a potential employer to new recruits, and as a supplier or partner to customers (Harding, 2003). The main objective of the employer branding concept is to positively influence current and to attract high-potential perspective employees (Berthon et al., 2005).

The study of employer branding practices proposes that the employer brand establishes the identity of firm as an employer (Dell, Ainspan, Bodenberg, Troy, \& Hickey, 2001). It encompasses the firms' values, system, policies, and behaviors toward the objectives of attracting, motivating, and retaining the firms' current and potential employees" (Backhaus \& Tikoo, 2004; Dell et al., 2001). These definitions indicate that employer branding involves promoting, both within and outside the firm, a clear view of what makes a firm different and desirable as an employer. Wilden, Gudergan \& Ling (2010) relate employer branding to the whole concept of brand equity and signaling theory which relates to brand signals that can be used to develop and communicate the qualities of the company to potential employees. Potential employees who do not have sufficient information or when the information is inconsistent or incorrect about a potential company, often perceive a higher risk associated with making a decision about that company (Wilden, Gudergan \& Ling 2010).

Kucherov \& Zavyalova (2012) identified a typology which divided employer branding attributes into 4 categories. These included (1) economic attributes such as salary, rewards, work schedules and workplace stability (2) psychological attributes such as strong corporate culture, positive interpersonal relations in the company, team building etc (3) functional attributes such as content of work, training, career growth etc and (4) organizational attributes such as leadership in market segment, international scope, company history, consumer reputation, and reputation of top management. 


\subsection{Benefits of Strong Employer Branding}

Backhaus and Tikoo (2004) suggested that employer branding can influence organizational identity and employer brand associations as well as how it correlates with organizational culture (Backhaus, 2004). A strong employer brand can lower turnover rates, lower recruitment costs, and increase the retention of employees. Ultimately, the efforts of employer branding can reduce the company's expenses and increase their revenues (Great Place to Work Institute, 2008). Brands play a major role in job choice and a strong employer brand contributes to favorable employee attitudes (Berthon et al., 2005; DelVecchio, Jarvis, Klink, \& Dineen, 2007). Strong employer branding can aid job seekers to differentiate hiring organizations from each other and create a competitive advantage for organizations. It also influences job application intentions (Backhaus, 2004; Lievens \& Highhouse, 2003; Rynes \& Barber, 1990; Turban \& Greening, 1997).

Chapman (2005) suggested a strong relationship between organizational attractiveness perceptions and applicant decisions such as job pursuit, acceptance, and choice intentions (Turban \& Cable, (2003) Roberson, Collins, \& Oreg (2005) proposed that organizational attractiveness mediates the relationship between the recruitment message and intentions to accept a job offer. Several recruitment studies suggested that perceived attitudes and attributes toward a job opportunity influence job seekers' early reactions to potential employers (Gatewood et al., 1993; Highhouse et al., 1999; Turban \& Greening, 1997). An employer brand is the sum of all the characteristics and distinguishable features that prospective candidates and current employees perceive about an organization's employment experience (Barrow \& Mosley, 2005).

\subsection{Use of Employer Branding}

Employer branding has been used by firms in an increasing amount to not only attract recruits but to assure that current employees are engaged in the culture of the firm. A closely related concept to "employer branding" is the notion of "employer attractiveness", defined as the envisioned benefits that a potential employee sees in working for a specific organization. It constitutes an important concept in knowledge-intensive contexts where attracting employees with superior skills and knowledge comprises a primary source of competitive advantage. The more attractive an employer is perceived to be by potential employees, the stronger that particular organization's employer brand equity (Berthon et al., 2005).

\section{Methodology}

\subsection{Sampling Frame and Context}

Undergraduate students studying at a major Midwestern university constituted the study's sample. Permission was given to the researchers to contact professors and instructors of each class. Professors allowed the researchers to distribute surveys their classes. Each professor gave the researcher the number of students in each class and a time to deliver the surveys to those classes. Classes were at all levels of the undergraduate curriculum. The purpose of the study was explained to the participants of each class. Participants were asked to complete the survey, place it in supplied envelopes, and put the envelope in a box placed in front of the classroom. No names were used on any surveys or envelopes to maintain the confidentiality of all individual results.

\subsection{Survey Design and Survey Instrument}

Based on thorough literature review, a self-administered questionnaire was developed based on some of the components of employer branding suggested by Ambler and Barrow (1996) and additional items that came from related literature (Berthon et al., 2005; C. J. Collins, 2007; C. J. Collins \& Stevens, 2002; Knox \& Freeman, 2006; Turban, 2001; Wildes \& Tepeci, 2004). In this research, one of the constructs which was known in the literature as economic benefits was relabeled as 'compensation and benefits'.

The questionnaire was comprised of two sections. The first section of the questionnaire consisted of 10 questions which asked for potential employees' opinions related to the importance of compensation and benefits offered by the employer and characteristics of that company that make students want to work for them. Students were asked about such factors as salary, compensation, medical and dental insurances, and moving expenses. For example, statements asked to students included, "A company that offers an above average or high starting salary for someone with bachelor's degree qualifications", "A company that provides me with above average benefits (such as medical, dental, and life insurance policies)", " A company that has a fully funded retirement plan", and "A company that offers paid opportunities for advanced degrees". All the statements, in this sections were measured on a five-point Likert scale ( 1 = very unimportant, $2=$ unimportant, $3=$ neutral, $4=$ important, and $5=$ very important $)$ to rate the importance of three components of employer branding in respondents' perceptions of employer branding. The higher the score, the more important the items were to potential employees' (university students') attitudes, perceptions of the company and brand. 
The last section of the questionnaire included demographic questions, such as gender, age, year in school, prior work experience, and segments of the industry which students focused on and, students' perceptions of recruiters' behavior.

Prior to finalizing the questionnaire, a pilot test was conducted to refine the research instrument with a group of students. Participants' suggestions were incorporated accordingly in the revision of the questionnaire. In addition, the pilot test was conducted to assess the reliability of the measures.

\section{Results}

There were a total of 348 responses. The demographic characteristics of the respondents are presented in below. The sample had a high percentage with 216 females $(62.2 \%)$ compared to 132 males $(37.8 \%)$. In relation to academic level, 21 respondents $(6 \%)$ were freshmen and 59 (17\%) sophomores. Juniors accounted for 115 respondents (33\%). The largest group seniors comprising $44 \%$ of the total with 153 respondents. Regarding grade point average (GPA), a high percentage of the respondents $(44 \%)$ had a GPA of between 3.0 and 3.5. The second largest number of respondents was the group 3.5 and above GPA (33\%). Nineteen percent were between 2.5 and 3.0 GPA. The group with GPAs of below 2.5 accounted for only $4 \%$ of the total.

In regards to the number of internships that respondents experienced, the largest percentage (38\%) said that they had no internship experience and $36 \%$ said that they had one internship experience. A total of $21 \%$ of the respondents had two internships, and 5\% of the respondents had done three internships. To analyze the length of industry work experience, $35.0 \%$ of respondents had worked for more than 2 years. Students who had worked for less than 6 months accounted for $32.7 \%$ and from 6 months to 1 year of experience was $13.6 \%$. Students from one year to two years of work experience accounted for $16.3 \%$ of the respondents.

\subsection{Students' Perceptions of Compensation and Benefits as a Component of Employer Branding}

The items for measuring the students' perceptions of compensation and benefits regarding employer branding are presented in Table 1. Students were asked to answer 10 statements which measured the importance they perceived towards compensation and benefits as one dimension of employer branding. All items were assessed using a five point Likert scale $(1=$ being very unimportant and $5=$ very important $)$. To use students' perceptions of compensation and benefits as a dependent variable, the researcher used the mean score combining each score of 10 items provided by each respondent. The means for each statement are presented in Table 1. Responses for the perceptions of compensation and benefits had a mean (for eleven items) of 3.83. For reliability checks, Cronbach's coefficient alpha was computed for each scale as a measure of internal consistency reliability.

Students reported that the most important things to them were, good benefits such as medical, dental and life insurance. This was followed by a good retirement plan in which employers would match contributions. The next group of items related to higher starting salary, and paid opportunities for advanced degrees. On the lower end of the spectrum were things such as pet insurance, childcare, working abroad, and access to an EAP.

Table 1. Students' perceptions of compensation and benefits

Items Used to Assess Students' Perceptions of Compensation and Benefits

Mean (10 items) $(\mathrm{N}=348)$

\begin{tabular}{lc}
\hline $\begin{array}{l}\text { A company that provides me with above average benefits (such as medical, dental, and } \\
\text { life insurance policies) }\end{array}$ & 4.30 \\
\hline A company that has a retirement plan in which they would match my contribution & 4.23 \\
\hline $\begin{array}{l}\text { A company that offers an above average or high starting salary for someone with } \\
\text { bachelor's degree qualifications }\end{array}$ & 4.19 \\
\hline A company that has a fully funded retirement plan & 4.18 \\
\hline A company that offers paid opportunities for advanced degrees & 4.13 \\
\hline A company that offers legal insurance & 3.91 \\
\hline A company that has an Employee Assistance Program & 3.66 \\
\hline A company that offers me the opportunity to work abroad & 3.50 \\
\hline A company that would offer paid or subsidized child care & 3.46 \\
\hline A company that offers pet insurance Mean & 2.70 \\
\hline
\end{tabular}

All items were measured on a five-point Likert scale from 1 (Very Unimportant) to 5

(Very Important). 


\section{Discussion and Conclusions}

The results of the present study demonstrated the perception of one important component of employer branding as viewed by students at one university the United States. More specifically, the research examined students' perceptions of a major component of compensation and benefits.

Certain organizational characteristics enhanced applicants' expectations of receiving an offer and were also were related to attraction to the organization (Chapman et al., 2005). If students' perceptions were very positive it could be more predictive of whether they may accept a job offer from the company.

Findings of the study give valuable suggestions to researchers and practitioners in industry. The study highlights the importance of compensation and benefits as a component of employer branding for improving students' perceptions of the company. Gender, GPA, leadership experience, industry work experience should be looked at in relation to the various factors which enhance employer branding. These results align with some of the attributes identified by Lievens and Highhouse (2003). Findings offer several implications to various stakeholders such as industry practitioners and educators.

\subsection{Practical Implications Include the Following.}

1. Cable and Turban (2001) noted that a potential applicant's knowledge of the benefits that an organization offers may influence the success of recruitment. For example, results of the present research affirmed that students' work experience with a company influences their perceptions of their brand. Companies that are perceived as having a strong brand image by students who had worked for that company will be better able to attract valued and talented applicants. Companies spend large amount of money on college recruiting efforts such as career fairs and interviewing on campus, yet companies need to do a better job of measuring how potential students perceive the company based on their previous work experience with the company.

Equally important is for companies to measure how their employer brand is perceived not only by students who are recruited on campus but those who seek employment with the company through direct placement because only 2 percent of new managers are coming directly through campus recruiting (Cho, Woods \& Sciarini 2006).

2. The brand as represented though a company's compensation and benefits can be the key to attracting future employees (Hieronimus, Schaefer, \& Schroder, 2005) since brands play a major role in job choice (DelVecchio et al., 2007). Furthermore, employees are critical to customer satisfaction and organizational performance (Lado \& Wilson, 1994) in the service industry. An organization gains a hiring advantage by leveraging the brand (Kim et al., 2011). Therefore, it will be valuable for practitioners in industry to recognize the significance of a strong employer brand as it relates to overall product quality and service and its relation to having valued employees. Human resource managers should promote their brand differently according to a variety of characteristics.

3. Employer branding is related to the building of external brand image since job applicants are potential employees and potential customers. A company may achieve its greatest advantage when the company identifies factors affecting employer branding and manages those factors efficiently. Based on previous studies, students (potential employees) used positive internship experiences with a company and word-of-mouth from fellow students who have worked for a company as an indication for evaluating an employer. Thus, treating internship students will bring benefits to companies when it comes to attracting potential graduates.

4. To understand what students truly want, companies need to communicate with students through lectures and other forms of activities on campus such as career fair and company information session. During these activities, companies can convey their brand and inform students their philosophy or culture including work environment. To build positive and ideal employer branding, companies need to participate at more career fair activities in universities and have more sponsored events, such as student invitations to business operation locations. Since brand is not a reality and is based solely upon feelings, impressions, perceptions, belief, and attitudes toward a company (Hsieh et al., 2004) through these activities, students can develop more positive attitudes toward those companies which are familiar to them, and they can see and know the work environment of future employers in advance. Therefore, efforts of frequent contact and interaction with students would provide positive feedback and outcomes for companies. For example, companies hold focus groups of students to ascertain how their company is perceived. Companies could upgrade their strategies to attract potential employees from student feedback. Companies can be assisted by student feedback about their interactions with recruiters and whether students are getting the proper information 
about things such as compensation and benefits. For example, a survey of students who interviewed with a certain company could provide valuable comments and suggestions for companies to improve their recruiting skills and recruiter behaviors.

5. Hospitality educators need to keep tabs on student perceptions of companies that recruit on campus as well as ones that hire their students. When companies have a less than stellar reputation among graduates who have worked for them or who have done internships with the company, it should be up to the faculty or department head to discuss this with companies. Some individuals within the company might not be aware of some of the issues that students have faced. Students word of mouth comments get around quickly and can do damage to a company.

\section{Limitations and Recommendations for Future Research}

The present study has some limitations which should be addressed to assure more effective research in the future. First, results were based on a convenience sample. Data from the current study was collected from students from only one university. Thus, findings of the study may not be generalizable to other populations. Second, the researcher only measured general perceptions of compensation and benefits; actual intentions were not measured.

Future research could seek to replicate these findings in other contexts and populations. Future research could expand the sample to include more students, more campuses, more schools, in other geographical locations. The magnitude and direction of students' perceptions of employer branding may be different. Future research could focus on looking at how these factors differ according to various departments such as business management, engineering, liberal arts, or law. In this study, only 10 questions were used to measure perceptions of compensation and benefits to assess students' perceptions of compensation and benefits. For future research, questions could be expanded to other factors related employer branding. If a specific company desired to measure how students view their company, results of the study could be coded and the information would then be useful to provide specific directions for a company to improve their employer branding. Finally, by examining current employees' perceptions of a company's brand image, an organization could compare its own perceptions of its brand with potential employees' perceptions of its brand image.

\section{References}

Ambler, T., \& Barrow, S. (1996). The employer brand. London: London Business School.

App, S., Merk, J., \& Buttgen, M. ( 2012). Employer Branding: Sustainable HRM as a competitive advantage in the market for high quality employees. Management Revue, 23(3), 262-278.

Backhaus, K. B. (2004). An exploration of corporate recruitment descriptions on Monster.com. Journal of Business Communication, 41(2), 115-136. http://dx.doi.org/10.1177/0021943603259585

Backhaus, K. B., Stone, B. A., \& Heiner, K. (2002). Exploringthe Relationship between Corporate Social Performance and Employer Attractiveness. Business \& Society, 41(3), 292. http://dx.doi.org/10.1177/0007650302041003003

Backhaus, K. B., \& Tikoo, S. (2004). Conceptualizing and researching employer branding. Career Development International, 9(5), 501-517. http://dx.doi.org/10.1108/13620430410550754

Barr, T. F., \& McNeilly, K. M. (2002). The value of students' classroom experiences from the eyes of the recruiter: Information, implications, and recommendations for marketing educators. Journal of Marketing Education, 24(2), 168-173.

Barrow, S., \& Mosley, R. (2005). The Employer Brand: bringing the best of brand management to people at work. John Wiley \& Sons, Ltd.

Berthon, P., Ewing, M., \& Hah, L. L. (2005). Captivating company: dimensions of attractiveness in employer branding. International Journal of Advertising, 24(2), 151-172.

Branham, L. (2001). Keeping the people who keep you in business: 24 ways to hang on to your most valuable talent. Amacom Books.

Brannan, M. J., Parsons, E., \& Priola, V. (2011). Branded Lives: The Production and Consumption of Meaning at Work. Notthampton, MA: Edward Elgar Publishing. http://dx.doi.org/10.4337/9780857938145

Cable, D. M., \& Turban, D. B. (2003). The Value of Organizational Reputation in the Recruitment Context: A Brand Equity Perspective. Journal of Applied Social Psychology, 33(11), 2244-2266. http://dx.doi.org/10.1111/j.1559-1816.2003.tb01883.x 
Chapman, D. S., Uggerslev, K. L., Carroll, S. A., Piasentin, K. A., \& Jones, D. A. (2005). Applicant attraction to organizations and job choice: a meta-analytic review of the correlates of recruiting outcomes. Journal of Applied Psychology, 90(5), 928-944. http://dx.doi.org/10.1037/0021-9010.90.5.928

Chhabra, N.L., \& Sharma, S. (2014). Employer Branding: Strategy for Improving Employer Attractiveness. International Journal of Organizational Analysis, 22(1), 48-60. http://dx.doi.org/10.1108/IJOA-09-2011-0513

Cho, S., Woods, R. H., \& Sciarini, M. (2006). How Hospitality Students Develop Perceptions of Potential Employers. Cornell Hotel and Restaurant Administration Quarterly, 47(2), 135-145. http://dx.doi.org/10.1177/0010880405286013

Chuang, N. K. (2011). Job-Related Barriers and Coping Behaviors in the Career Development of Hospitality Undergraduates. Journal of Human Resources in Hospitality \& Tourism, 10(1), 14-31. http://dx.doi.org/10.1080/15332845.2010.500183

Chuang, N. K., \& Dellmann-Jenkins, M. (2010). Career Decision Making and Intention: a Study of Hospitality Undergraduate Students. Journal of Hospitality \& Tourism Research, 34(4), 512-530. http://dx.doi.org/10.1177/1096348010370867

CIPD. (2009). Employer branding: maintaining momentum in a recession. Chartered Institute of Personnel and Development (CIPD) Guide.

Collins, C. J. (2007). The interactive effects of recruitment practices and product awareness on job seekers' employer knowledge and application behaviors. Journal of Applied Psychology, 92(1), 180-190. http://dx.doi.org/10.1037/0021-9010.92.1.180

Collins, J. C. (2001). Good to great: Why some companies make the leap--and others don't. New York: Harper Business.

Connerley, M. L., \& Rynes, S. L. (1997). The influence of recruiter characteristics and organizational recruitment support on perceived recruiter effectiveness: Views from applicants and recruiters. Human Relations, 50(12), 1563-1586. http://dx.doi.org/10.1177/001872679705001205

Corte, D.V., Mangia, G., \& Zamparelli, G. (2011). Strategic Employer Branding: Brand and Image Management as a Tool of Attractiveness for Talented Capital. China-USA Business Review, 10(12), 1231-1252.

De Chernatony, L., \& Segal-Horn, S. (2003). The criteria for successful services brands. European Journal of Marketing, 37(7/8), 1095-1118. http://dx.doi.org/10.1108/03090560310477681

Dell, D., Ainspan, N., Bodenberg, T., Troy, K., \& Hickey, J. (2001). Engaging employees through your brand. Paper presented at the The Conference Board, New York.

DelVecchio, D., Jarvis, C. B., Klink, R. R., \& Dineen, B. R. (2007). Leveraging brand equity to attract human capital. Marketing Letters, 18(3), 149-164. http://dx.doi.org/10.1007/s11002-007-9012-3

Edwards, M. R. (2005). Employer and employee branding: HR or PR? Managing human resources: personnel management in transition, pp. 266-286.

Ehrhart, K. H., \& Ziegert, J. C. (2005). Why are individuals attracted to organizations? Journal of management, 31(6), 901-919. http://dx.doi.org/10.1177/0149206305279759

Fortune. (2011). 100 best companies to work for Retrieved February 25, 2012, from HTTP:/MONEY.CNN.COM/MAGAZINES/FORTUNE/BESTCOMPANIES/2011/FULL_LIST/

Gatewood, R. D., Gowan, M. A., \& Lautenschlager, G. J. (1993). Corporate image, recruitment image, and initial job choice decisions. The Academy of Management Journal, 36(2), 414-427. http://dx.doi.org/10.2307/256530

Hieronimus, F., Schaefer, K., \& Schroder, J. (2005). Using branding to attract talent. The McKinsey Quarterly, 3, $12-14$.

Highhouse, S., Zickar, M. J., Thorsteinson, T. J., Stierwalt, S. L., \& Slaughter, J. E. (1999). Assessing company employment image: An example in the fast food industry. Personnel Psychology, 52(1), 151-172. http://dx.doi.org/10.1111/j.1744-6570.1999.tb01819.x

Hsieh, M. H., Pan, S. L., \& Setiono, R. (2004). Product-, Corporate-, and Country-Image dimensions and purchase behavior: A Multicountry Analysis. Journal of the Academy of Marketing Science, 32(3), 251-270. http://dx.doi.org/10.1177/0092070304264262 
Joo, B. K., \& McLean G. N. (2006). Best Employer Studies: A conceptual model and literature review. Human Resources Development Review, 5(2), 228-257. http://dx.doi.org/10.1177/1534484306287515

Kim, J., York, K. M., \& Lim, J. S. (2011). The role of brands in recruitment: A mixedbrand strategy approach. Marketing Letters, 22(2), 165-179. http://dx.doi.org/10.1007/s11002-010-9119-9

Knox, S., \& Freeman, C. (2006). Measuring and managing employer brand image in the service industry. Journal of Marketing Management, 22(7), 695-716. http://dx.doi.org/10.1362/026725706778612103

Kucherov, D. \& Zavyalova, E. (2012). HRD practices and Talent management in companies with the employer brand. European Journal of Training and Development, 36(1), 86-104. http://dx.doi.org/10.1108/03090591211192647

Lievens, F., Decaesteker, C., Coetsier, P., \& Geirnaert, J. (2001). Organizational attractiveness for prospective applicants: A Person-Organisation fit perspective. Applied Psychology, 50(1), 30-51. http://dx.doi.org/10.1111/1464-0597.00047

Lievens, F., \& Highhouse, S. (2003). The relation of instrumental and symbolic attributes to a company's

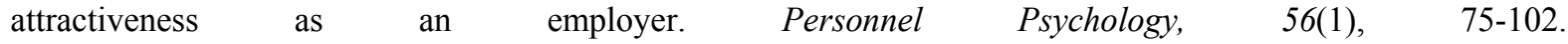
http://dx.doi.org/10.1111/j.1744-6570.2003.tb00144.x

Lloyd, S. (2002). Branding from the inside out. Business Review Weekly, 24(10), 64-66.

Love, L.F. (2011) Workplace Branding: Leveraging Human Resource Management Practices for Competitive Advantage. Journal of Business Psychology, 26, 175-181. http://dx.doi.org/10.1007/s10869-011-9226-5

Lyon, D.B., \& Mahler, H. J. (2011). Examining Organizational Image on Web Recruitment. Journal of Managerial Psychology, 26(1), 58-76. http://dx.doi.org/10.1108/02683941111099628

Maxwell, R., \& Knox, S. (2009). Motivating employees to" live the brand": a comparative case study of employer brand attractiveness within the firm. Journal of Marketing Management, 25(9), 893-907. http://dx.doi.org/10.1362/026725709X479282

Meffert, H., Burmann, C., \& Koers, M. (2002). Stellenwert und Gegenstand des Markenmanagement. Markenmanagement. Grundfragen eineridentit?sorientierten Markenf?rung (S. 3-14). Wiesbaden: Gabler. http://dx.doi.org/10.1007/978-3-322-92976-1

Minchington, B., \& Thorne, K. (2007). Measuring the Effectiveness of Your Employer Brand. Human Resources Magazine.

Moroko, L., \& Uncles, M. D. (2008). Characteristics of successful employer brands. Journal of Brand Management, 16(3), 160-175. http://dx.doi.org/10.1057/bm.2008.4

Mosley, R. (2009). Employer Brand: The performance driver no business can ignore. 4-15. Retrieved from http://www.marksherrington.com/downloads/Richard\%20Mosley\%20eArticle.pdf

Ong, L.D. (2011). Employer Branding and Its Influence on Potential Job Applicants. Australian Journal of Basic and Applied Sciences, 5(9), 1088-1092.

Peter, T. J. (1999). The brand you 50: Fifty ways to transform yourself from an"employee" into a brand that shouts distinction. New York: Knopf Publishers.

Rynes, S. L. (1991). Recruitment, job choice, and post-hire consequences: A call for new research directions. Handbook of industrial and organizational psychology, 2, 399-444.

Rynes, S. L., \& Barber, A. E. (1990). Applicant attraction strategies: An organizational perspective. The Academy of Management Review, 15(2), 286-310.

Rynes, S. L., Bretz Jr, R. D., \& Gerhart, B. (1991). The importance of recruitment in job choice: A different way of looking. Personnel Psychology, 44(3), 487-521. http://dx.doi.org/10.1111/j.1744-6570.1991.tb02402.x

Sullivan, J. (2004). Eight elements of a successful employment brand. ER Daily, 23, 501-517.

Thomas, K. M., \& Wise, P. G. (1999). Organizational attractiveness and individual differences: Are diverse applicants attracted by different factors? Journal of Business and Psychology, 13(3), 375-390. http://dx.doi.org/10.1023/A:1022978400698

Thorne, K. (2004). One-stop guide: Employer branding. Personnel Today, 30. 
Turban, D. B. (2001). Organizational attractiveness as an employer on college campuses: An examination of the applicant population. Journal of Vocational Behavior, 58(2), 293-312. http://dx.doi.org/10.1006/jvbe.2000.1765

Turban, D. B., \& Cable, D. M. (2003). Firm reputation and applicant pool characteristics. Journal of Organizational Behavior, 24(6), 733-751. http://dx.doi.org/10.1002/job.215

Turban, D. B., \& Greening, D. W. (1997). Corporate social performance and organizational attractiveness to prospective employees. The Academy of Management Journal, 40(3), 658-672. http://dx.doi.org/10.2307/257057

Twenge, J. M., Campbell, S. M., Hoffman, B. J., \& Lance, C. E. (2010). Generational differences in work values: Leisure and extrinsic values increasing, social and intrinsic values decreasing. Journal of Management, 36, 1117-1142. http://dx.doi.org/10.1177/0149206309352246

Wilden, R., Gudergan, S., \& Lings, I. (2010). Employer branding: strategic implications for staff recruitment. Journal of Marketing Management, 26(1), 56-73. http://dx.doi.org/10.1080/02672570903577091

Wildes, V. J., \& Tepeci, M. (2004). Influences of campus recruiting on applicant attraction to hospitality companies. Journal of Human Resources in Hospitality \& Tourism, 2(1), 39-51. http://dx.doi.org/10.1300/J171v02n01_03

Willock, R. (2005, May 17). Employer branding is key in fight for talent. Personnel Today, p. 4.

Yaqub B., \& Khan, M.A. (2011). The role of employer branding and talent management for Organizational attractiveness. Far East Journal of Psychology and Business, 5(1). 